\title{
Synthesis and determination of the absolute configuration of (-)-(5R,6Z)-dendrolasin-5-acetate from the nudibranch Hypselodoris jacksoni
}

\author{
I. Wayan Mudianta ${ }^{1}$, Victoria L. Challinor ${ }^{1}$, Anne E. Winters ${ }^{2}$, \\ Karen L. Cheney ${ }^{2}$, James J. De Voss ${ }^{1}$ and Mary J. Garson ${ }^{* 1}$
}

\section{Full Research Paper}

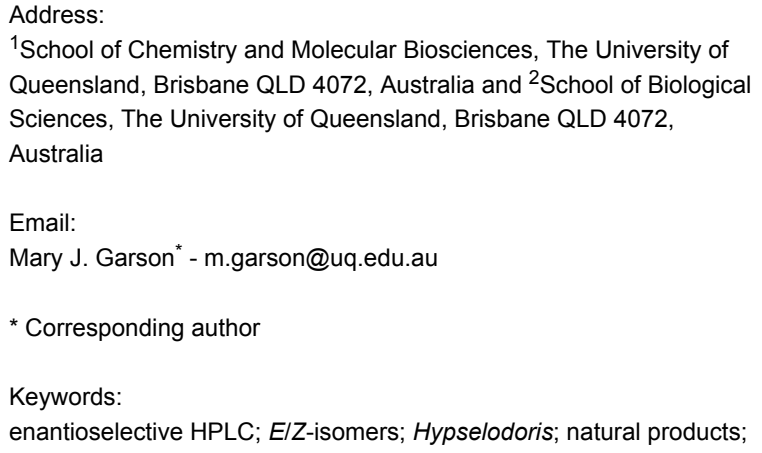

${ }^{1}$ School of Chemistry and Molecular Biosciences, The University of Queensland, Brisbane QLD 4072, Australia and ${ }^{2}$ School of Biological Sciences, The University of Queensland, Brisbane QLD 4072,

Australia

Email:

Mary J. Garson* - m.garson@uq.edu.au

* Corresponding author

Keywords:

enantioselective HPLC; E/Z-isomers; Hypselodoris; natural products; nudibranch; sesquiterpene
Beilstein J. Org. Chem. 2013, 9, 2925-2933.

doi:10.3762/bjoc.9.329

Received: 11 September 2013

Accepted: 21 November 2013

Published: 23 December 2013

This article is part of the Thematic Series "Natural products in synthesis and biosynthesis".

Guest Editor: J. S. Dickschat

(C) 2013 Mudianta et al; licensee Beilstein-Institut. License and terms: see end of document.

\begin{abstract}
A small sample of (-)-(5R,6Z)-dendrolasin-5-acetate, which was fully characterized by 2D NMR studies, was isolated from the nudibranch Hypselodoris jacksoni, along with the sesquiterpenes (+)-agassizin, (-)-furodysinin, (-)-euryfuran, $(-)$-dehydroherbadysidolide and (+)-pallescensone. A synthetic sample $\left([\alpha]_{\mathrm{D}}-8.7\right)$ of the new metabolite was prepared by $[1,2]-$ Wittig rearrangement of a geranylfuryl ether followed by acetylation of purified alcohol isomers. The absolute configuration at $\mathrm{C}-5$ was established as $R$ by the analysis of MPA ester derivatives of (Z)-5-hydroxydendrolasin obtained by preparative enantioselective HPLC.
\end{abstract}

\section{Introduction}

Marine organisms have been proven a prolific source of natural products that potentially can be used as lead compounds or which have inspired synthetic chemists as synthetic targets [1]. Similarly, extensive studies of marine chemical ecological interactions have enriched our knowledge of biological and evolutionary patterns, and of the role of small molecules in chemical defensive strategies underwater [2,3]. Nudibranchs (Mollusca: Gastropoda: Opisthobranchia) are a group of marine animals that use small molecules for a variety of purposes, including communication, reproduction, and defense against predation $[4,5]$. These molecules have been extensively studied and as of 2012, seven out of the 20 natural products of marine origin (either directly or as a derivative) that have been approved for FDA use as a drug or are in clinical trials were first isolated from molluscs. For some of these bioactives, the actual biosynthetic source is a microorganism [6]. 
Within the Nudibranchia, the genus Hypselodoris is generally characterized by sesquiterpene chemistry, as evidenced by a number of studies on European [7-13], Indian [14], South African [15], Brazillian [16], and Indo-Pacific specimens [1720]. During a comparative biogeographical study on opisthobranch molluscs from South East Queensland, Australia, we encountered the new sesquiterpene $(-)-(5 R, 6 Z)$-dendrolasin-5acetate (1) in specimens of $H$. jacksoni along with the other known sesquiterpene metabolites $(+)$-agassizin, (-)-furodysinin, $(-)$-euryfuran, $(-)$-dehydroherbadysidolide, $(+)$-pallescensone. The new metabolite $\mathbf{1}$ has never been identified from natural sources, although the $6 E$-isomer 2 was previously reported in racemic form during the synthesis of naturally occurring dendrolasin (3) by Tsubuki et al. in 2009 [21] (Figure 1). Dendrolasin (3) itself has been isolated from both terrestrial and marine sources, including from the nudibranchs Chromodoris lochi [22], from three Hypselodoris spp. [18], and from the marine sponge Dictyodendrilla sp. [23]. The current study reports the isolation and synthesis of $(-)-(5 R, 6 Z)$-dendrolasin-5acetate (1), with the determination of the absolute configuration at $\mathrm{C}-5$ by spectroscopic analysis of the methoxyphenylacetic acid (MPA) derivative.

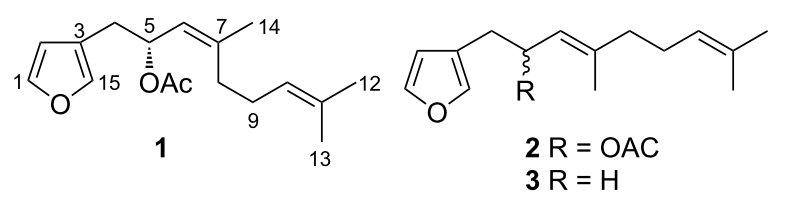

Figure 1: (-)-(5R,6Z)-Dendrolasin-5-acetate (1), its $6 E$ derivative and naturally occuring dentrolasin (3).

\section{Results and Discussion Isolation and structure elucidation of natural product 1}

Eight individuals of $H$. jacksoni were collected by SCUBA from two locations in SE Queensland. Owing to their small size (21-40 $\mathrm{mm})$, the specimens were not examined individually. Extraction into acetone followed by partitioning into diethyl ether gave an extract which was fractionated first by normal phase (NP) flash chromatography and then by preparative NP HPLC to give (+)-agassizin, (-)-furodysinin, (-)-euryfuran, $(-)$-dehydroherbadysidolide, $(+)$-pallescensone, and the new sesquiterpene $\mathbf{1}$.

Compound 1, $[\alpha]_{\mathrm{D}}-53\left(c 0.006, \mathrm{CHCl}_{3}\right)$, displayed a (+)HRESIMS ion adduct at $\mathrm{m} / z 299.1624[\mathrm{M}+\mathrm{Na}]^{+}$consistent with the molecular formula $\mathrm{C}_{17} \mathrm{H}_{24} \mathrm{O}_{3}$. The ${ }^{1} \mathrm{H}$ NMR spectrum $\left(\mathrm{CDCl}_{3}, 500 \mathrm{MHz}\right)$ of 1 showed diagnostic signals for a furan $\left[\delta_{\mathrm{H}} 7.33(1 \mathrm{H}), 7.23(1 \mathrm{H}), 6.27(1 \mathrm{H}) ; \delta_{\mathrm{C}} 142.7,140.1,111.8\right]$ along with two alkene signals $\left[\delta_{\mathrm{H}} 5.15(1 \mathrm{H}), 5.07(1 \mathrm{H}) ; \delta_{\mathrm{C}}\right.$ $123.7,123.9]$. Signals for three methyl groups were observed at $\delta_{\mathrm{H}} 1.72,1.67$, and 1.59 and were linked to signals at $\delta_{\mathrm{C}} 23.3$, 25.7, and 17.6, respectively, by HSQC. There were also signals characteristic of an acetate group $\left[\delta_{\mathrm{H}} 2.01(\mathrm{~s}, 3 \mathrm{H}) ; \delta_{\mathrm{C}} 21.4\right]$. These partial NMR assignments were comparable to those of the known dendrolasin (3), a sesquiterpene previously isolated from Hypselodoris cantabrica [9] and H. californiensis [18]. However, the signal corresponding to $\mathrm{H}-5$ in dendrolasin (3) was reported to be a multiplet $(2 \mathrm{H})$ resonating at $\delta_{\mathrm{H}} 2.21$ [24] whereas that in 1 was shifted to $\delta_{\mathrm{H}} 5.64$ (brdt, $J=6.4,9.3 \mathrm{~Hz}$, $1 \mathrm{H})$. The gCOSY spectrum of 1 showed cross peaks from $\mathrm{H}-5$ to $\mathrm{H}-4 / \mathrm{H}-6$, between the furan signals $\mathrm{H}-1 / \mathrm{H}-2$ and between $\mathrm{H}-8 / \mathrm{H}-9 / \mathrm{H}-10$. The $\mathrm{H}-5$ proton was attached to an oxymethine carbon at $\delta_{\mathrm{C}} 70.7$ based on HSQC data and showed HMBC correlations to neighbouring carbons including C-3 $\left(\delta_{\mathrm{C}} 120.2\right)$, C-7 $\left(\delta_{\mathrm{C}} 141.5\right)$, and the OAc carbonyl $\left(\delta_{\mathrm{C}} 170.2\right)$ (Figure 2$)$. HMBC correlations observed from the alkene proton $\mathrm{H}-6\left(\delta_{\mathrm{H}}\right.$ 5.15) to $\mathrm{C}-4, \mathrm{C}-7$, and $\mathrm{CH}_{3}-14$ secured the position of the double bond between C-6 and C-7. A second double bond was positioned between $\mathrm{C}-10$ and $\mathrm{C}-11$ based on HMBC correlations from the alkene proton $\mathrm{H}-10\left(\delta_{\mathrm{H}} 5.07\right)$ to $\mathrm{CH}_{3}-12$ and $\mathrm{C}-8$. The C-6/C-7 configuration was revealed as $Z$ rather than the $E$-configuration anticipated, based on $1 \mathrm{D}$ nOe experiments in which the signal intensity of $\mathrm{H}_{3}-14$ increased when the signal attributed to H-6 was irradiated (mixing time $60 \mathrm{~ms}$ ). 1D nOe irradiation of $\mathrm{H}-10$ provided assignment of the signals corresponding to $\mathrm{CH}_{3}-12$.

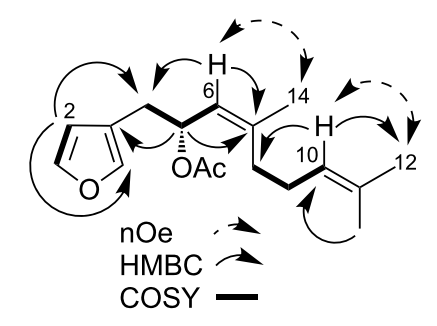

Figure 2: Selected HMBC, COSY, and nOe correlations of 1.

\section{Total synthesis of (-)-(5R,6Z)-dendrolasin-5- acetate (1)}

In view of the small sample $(0.1 \mathrm{mg})$ of natural material available, a synthetic study was undertaken to provide stereochemical characterization of $\mathbf{1}$, in particular the configuration at C-5. The synthesis, which was completed in five steps, involved preparation of 3-furylmethanol (4) and of geranyl bromide (5), etherification, [1,2]-Wittig rearrangement of geranyl 3-furylmethyl ether (6) to produce $\mathbf{7 a} / \mathbf{b}$, and acetylation to obtain target $\mathbf{1}$. The overall synthesis (Scheme 1) was adapted from Tsubuki et al. [21]. 


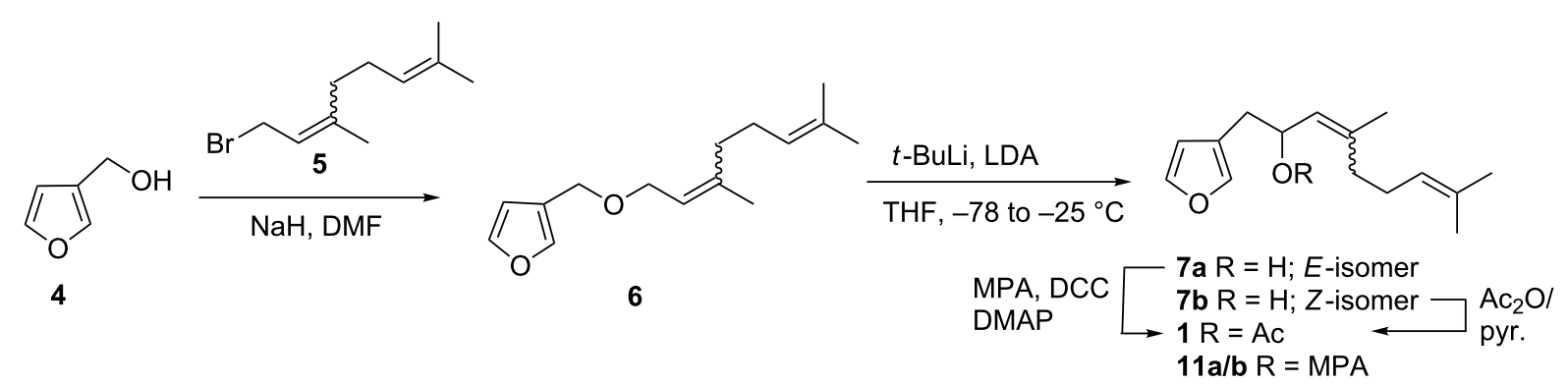

Scheme 1: Synthetic route to sesquiterpene 1.

Furan-3-ylmethanol (4) was prepared in $78 \%$ yield by reduction of 2-furoic acid with $\mathrm{LiAlH}_{4}$ in dry diethyl ether, whereas geranyl bromide (5) was obtained through bromination of geraniol with carbon tetrabromide and triphenylphosphine in $90 \%$ yield. The ${ }^{1} \mathrm{H}$ NMR spectrum of the geraniol sample used indicated the presence of traces of nerol, the $Z$-isomer of geraniol. Etherification of furan-3-ylmethanol (4) with the geranyl/neryl bromide mixture (5) in the presence of $\mathrm{NaH}$ furnished the 3-furylmethyl ether 6 (65\% yield) as an $E / Z$ mixture (3:1). The H-5 signal for the minor $Z$-isomer of 6 resonated at $\delta_{\mathrm{H}} 3.90(\mathrm{~d}, J=6.8 \mathrm{~Hz})$ compared to that of the $E$-isomer $\left(\delta_{\mathrm{H}} 4.00, \mathrm{~d}, J=6.8 \mathrm{~Hz}\right)$. Irradiation of the H-5 signal of the $Z$-isomer increased the intensity of the signal associated with the adjacent methyl $\left(\mathrm{CH}_{3}-14\right)$, confirming the $\mathrm{Z}$ double bond at $\mathrm{C} 6 / \mathrm{C} 7$. The isomeric mixture of 6 was immediately subjected to [1,2]-Wittig rearrangement with $t$-BuLi (4 equiv) and LDA at $-78{ }^{\circ} \mathrm{C}$ to afford racemic 5-hydroxydendrolasin (39\% yield), again as an $E / Z$ mixture $(\mathbf{7 a} / \mathbf{b})$ for which a $3: 1$ ratio was determined by ${ }^{1} \mathrm{H}$ NMR comparison with data for the individual stereoisomers (see below). The 3:1 ratio of $E / Z$-isomers was confirmed via analytical HPLC.
In principle, the rearrangement of 6 could afford either [1,2]rearranged products (e.g. $7 \mathbf{a} / \mathbf{b}$ or $\mathbf{8}$ ) or $[2,3]$-rearranged products such as $\mathbf{9}$ or $\mathbf{1 0}$ depending on which site adjacent to the ether oxygen is preferentially deprotonated (Scheme 2). A thermodynamic optimization study on the Wittig rearrangement of allyl 3-furylmethyl ether by Tsubuki et al. has revealed that deprotonation occurs mainly at the $\alpha$-position [21]. The results of this theoretical study are fully consistent with our synthetic work since the mixture of $\mathbf{7 a} / \mathbf{b}$ was the sole $[1,2]$-Wittig rearrangement product obtained.

Racemic 5-hydroxydendrolasin (7a/b) was next subjected to HPLC (hexanes/EtOAc, 90:10) to provide the individual $E$ - (7a) and $Z$-isomers (7b) that were each carefully characterised by ${ }^{1} \mathrm{H}$ NMR and 1D nOe experiments. Assignment of the upfield signals corresponding to the three methyl groups attached to the double bonds (Figure 3) was made using HMBC and nOe data. The signal for $\mathrm{CH}_{3}-14$ in the $Z$-isomer resonated downfield $\left(\delta_{\mathrm{H}} 1.74\right)$ compared to that in the $E$-isomer $\left(\delta_{\mathrm{H}} 1.65\right)$ while the signal for $\mathrm{H}-5$ appeared slightly upfield $\left(\delta_{\mathrm{H}} 4.48\right)$ in the $Z$-isomer compared to that in its $E$ counterpart $\left(\delta_{\mathrm{H}} 4.51\right)$.<smiles>[R]/C(C)=C/C[C@@H](O)c1ccoc1</smiles><smiles>[R]C(C)=C[C@@H](c1ccoc1)[C@H](O)C=C([R])C</smiles> 


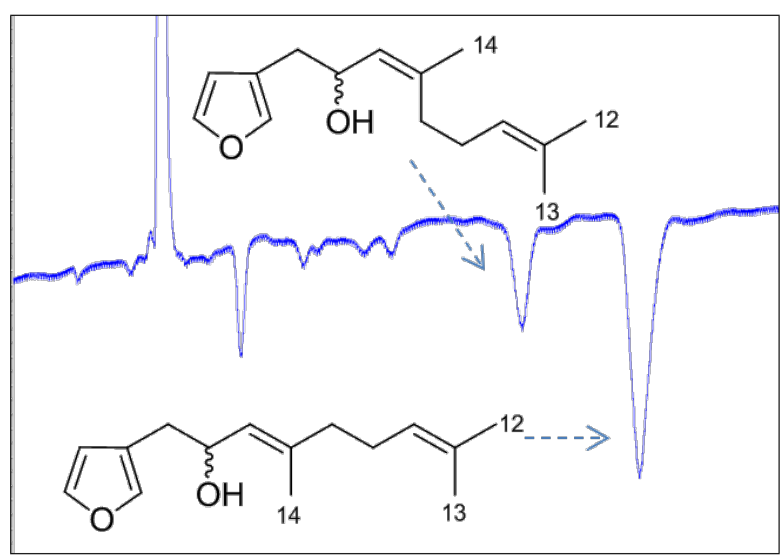

(a)

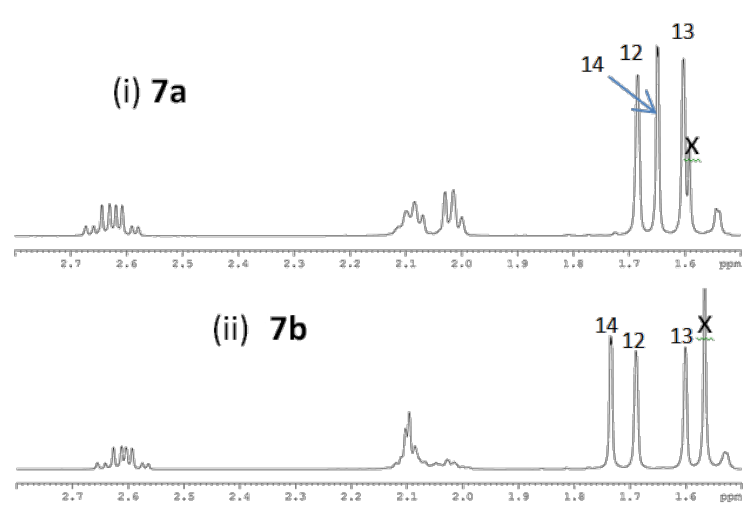

(b)

Figure 3: (a) NP HPLC trace showing separation of racemic 5-hydroxydendrolasin (7a/b) using hexanes/EtOAc (90:10; flow rate $2 \mathrm{~mL} / \mathrm{min}$ over 60 minutes (x axis)) and refractive index detection (y axis); (b) ${ }^{1} \mathrm{H}$ NMR spectroscopic comparison of (6E)-5-hydroxydendrolasin (7a) (i) and (6Z)-5hydroxydendrolasin $(\mathbf{7 b})$ (ii); $x=$ water signals.

1D NOESY irradiation of the $\mathrm{CH}_{3}-14$ signal for the $Z$-isomer resulted in enhancement of the alkene signal at $\delta_{\mathrm{H}} 5.24(\mathrm{H}-6)$, fully consistent with the $Z$ configuration; there was no corresponding nOe between $\mathrm{CH}_{3}-14$ and $\mathrm{H}-6$ in the $E$-isomer, although such data must be interpreted with care.

With the individual characterization of the $E / Z$-isomers accomplished, preparative enantioselective HPLC separation of racemic $(Z)$-5-hydroxydendrolasin (7b) was next undertaken (Figure 4 ) and provided samples of both of the $(+)-7 \mathbf{b}$ and $(-)-7 \mathbf{b}$ isomers, respectively. Treatment of each enantiomer of 7b with acetic anhydride and pyridine gave their acetate derivatives. Surprisingly, $(+)-7 \mathbf{b}\left([\alpha]_{\mathrm{D}}+9.3\right)$ gave an acetate derivative with $[\alpha]_{\mathrm{D}}-8.7$ and vice versa $\left([\alpha]_{\mathrm{D}}-12\right.$ for $(-)-7 \mathbf{b}$ and
$[\alpha]_{D}+13$ for its acetate derivative). As anticipated, the ${ }^{1} \mathrm{H}$ NMR spectrum $\left(\mathrm{CDCl}_{3}, 500 \mathrm{MHz}\right)$ of the synthetic sample of $(-)-(6 Z)-1$ was fully superimposable with that of the sample of (6Z)-dendrolasin-5-acetate isolated from H. jacksoni (Figure 5).

\section{Absolute configurational assignment of (6Z)- dendrolasin-5-acetate (1)}

It remained to determine the absolute configuration of C-5 in the natural acetate derivative. A portion of the racemic mixture of $\mathbf{7 b}$ was esterified with $(R)$-MPA acid in the presence of DMAP and DCC at room temperature to give a mixture of diastereomeric $(R, R)-\mathbf{1 1}$ and $(R, S)-\mathbf{1 1}$, which was separated by reversed phase (RP) HPLC $\left(\mathrm{MeCN} / \mathrm{H}_{2} \mathrm{O} ; 63: 35\right)$ (Figure 6). The H-6 protons in $(R, R)-\mathbf{1 1}$ and $(R, S)-\mathbf{1 1}$ resonated at $\delta_{\mathrm{H}} 5.04$ and

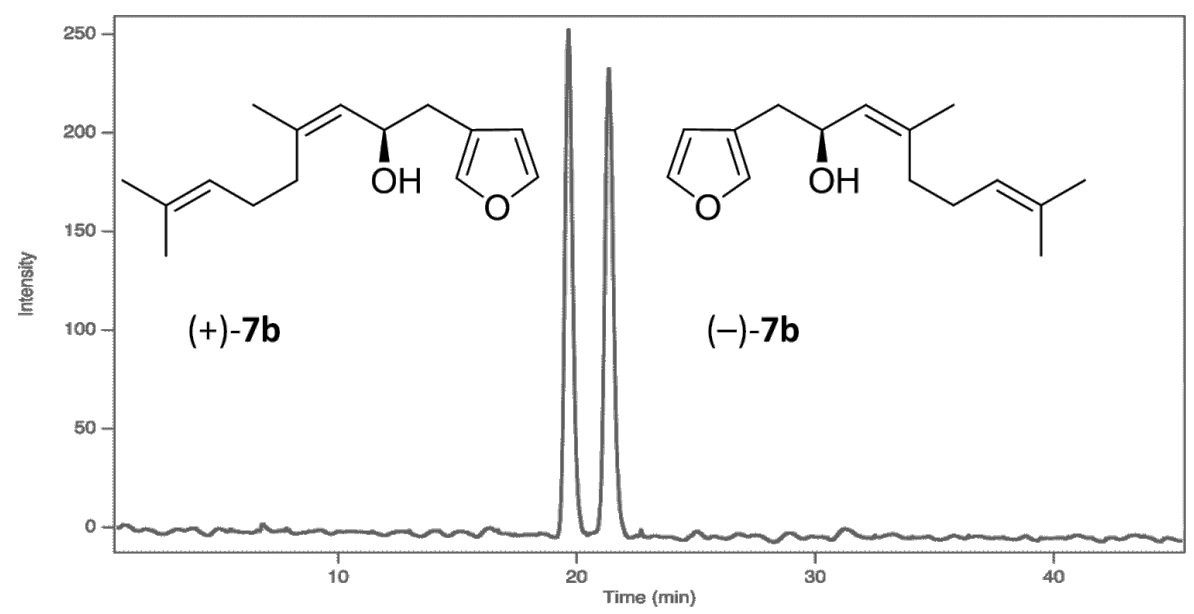

Figure 4: Analytical enantioselective HPLC trace showing separation of individual enantiomers of (6Z)-5-hydroxydendrolasin (Chiralpak AD column, $250 \times 4.6 \mathrm{~mm}, 2 \%$ IPA in $n$-hexane at $0.5 \mathrm{~mL} / \mathrm{min}$, UV detection at $214 \mathrm{~nm}$ ). 


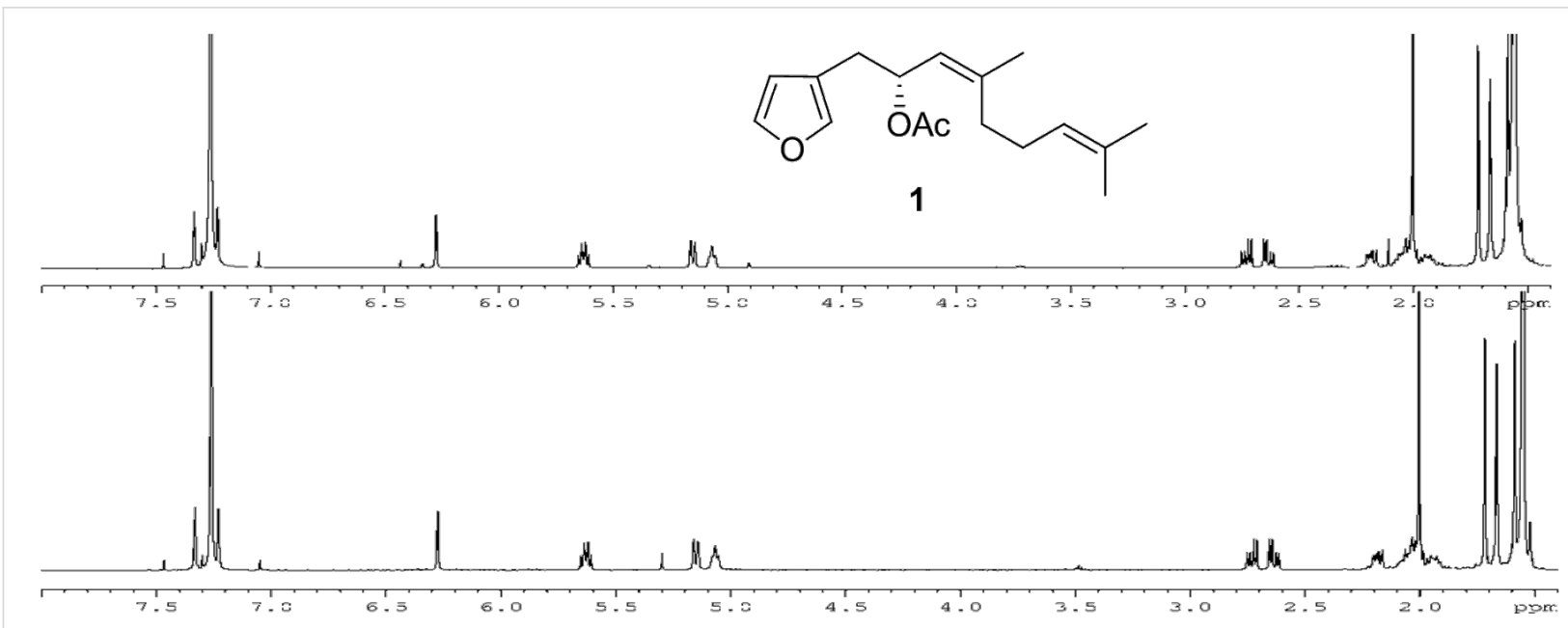

Figure 5: The ${ }^{1} \mathrm{H}$ NMR $\left(\mathrm{CDCl}_{3}, 500 \mathrm{MHz}\right)$ spectroscopic comparison of (6Z)-dendrolasin-5-acetate (1): (a) sample isolated from $\mathrm{H}$. jacksoni; (b) synthetic sample of $(-)-(6 Z)-1$.

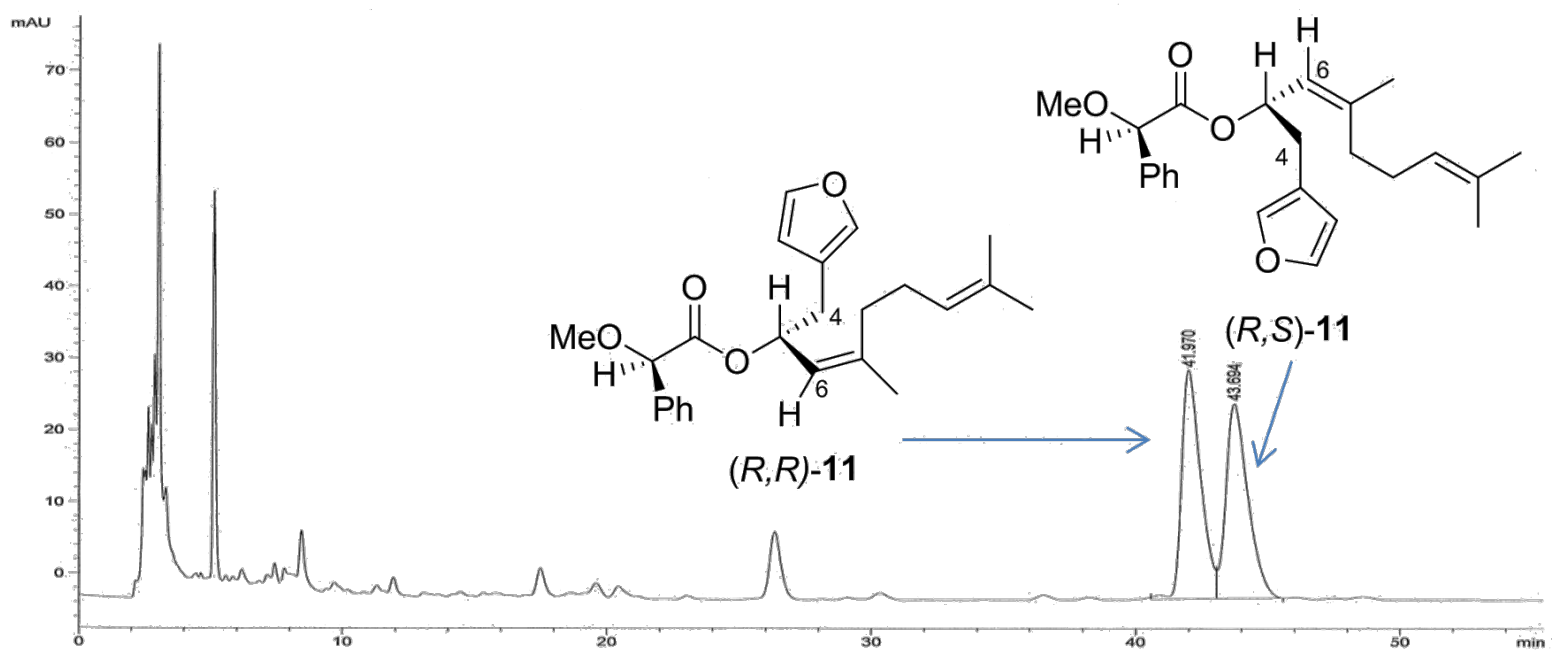

Figure 6: RP HPLC trace showing separation of the MPA esters $(R, R)-11$ and $(R, S)-11\left(\mathrm{MeCN} / \mathrm{H}_{2} \mathrm{O}, 63: 35\right.$ over 50 minutes, Phenomenex $\mathrm{C}-18$ column, $250 \times 4.60 \mathrm{~mm}$, UV detection at $254 \mathrm{~nm}$ ).

at $\delta_{\mathrm{H}} 5.13$, respectively, in agreement with $\mathrm{H}-6$ of the $(R, R)$ isomer positioned in the shielding cone of the aryl ring of the MPA moiety [25]. The diastereotopic H-4 signals in $(R, S)-\mathbf{1 1}$ at $\delta_{\mathrm{H}} 2.51$ and 2.58 were shielded compared to those in $(R, R)-\mathbf{1 1}$ $\left(\delta_{\mathrm{H}} 2.64,2.74\right)$. Likewise, the furan proton signals were shifted upfield in the $(R, S)$-isomer compared to the $(R, R)$-isomer. These data were in agreement with the configurations depicted in Figure 6. The MPA ester spectra acted as reference data for determination of the absolute configuration of the natural sample of dendrolasin-5-acetate (1). The individually-purified enantiomers of synthetic (6Z)-5-hydroxydendrolasin were each treated with $(R)$-MPA to give their respective MPA ester derivatives. The ${ }^{1} \mathrm{H}$ NMR spectra of the MPA ester of $(+)-7 \mathbf{b}$ was identical to that of the synthetic $(R, R)-\mathbf{1 1}$ and established that (+)-5-hydroxydendrolasin (7) has an $R$ configuration. Likewise, the ${ }^{1} \mathrm{H}$ NMR spectrum of the MPA ester of $(-)-7 \mathbf{b}$ was identical to that of the synthetic diastereomer $(R, S)$-11. Taking into account the change in sign of $[\alpha]_{D}$ between the alcohol and its acetate derivative, these data verified that the naturallyoccurring (-)-acetate 1 had a $5 R$ configuration.

Specific rotation values for 1 were measured as $[\alpha]_{D}-53$ for the natural sample and -8.7 for the synthetic sample. Despite having the same negative sign of specific optical rotation, the $[\alpha]_{\mathrm{D}}$ values of the natural sample was considerably larger than that of the synthetic sample. Although a partial explanation for 
the difference in values was apparent, namely that the natural sample size was small $(0.1 \mathrm{mg})$ compared to the synthetic sample size $(0.9 \mathrm{mg})$, better experimental evidence of their stereochemical uniformity was desirable. Enantioselective HPLC analyses run under identical conditions using 5\% isopropanol in $n$-hexane were carried out on the synthetic sample of racemic 1 , the two synthetically prepared $R$ and $S$ enantiomers of $\mathbf{1}$, and the natural sample as shown in Figure 7. The data revealed a clear separation of the individual enantiomers of $\mathbf{1}$ (shown in trace (a)), and that the (+)-enantiomer elutes before the (-)-enantiomer (traces (b) and (c)). Finally, the natural sample has the same retention time as the (-)-enantiomer (trace (d)). A co-injection experiment performed on a mixture of the synthetic $(+)$-enantiomer and the natural sample consistently displayed two peaks in which the former compound eluted before the natural sample.

\section{Conclusion}

Chemical investigation of $H$. jacksoni collected from Queensland yielded a new sesquiterpene $(5 R, 6 Z)$-dendrolasin-5-acetate (1) whose structure and stereochemistry were confirmed by means of a five-step synthesis involving [1,2]-Wittig rearrangement of geranyl furyl ether (6) followed by acetylation of the purified alcohol products. The absolute configuration in $\mathbf{1}$ was established as $5 R$ by detailed comparison with MPA ester derivatives prepared from individual enantiomers of synthetic
(6Z)-5-hydroxydendrolasin purified by preparative enantioselective HPLC.

\section{Experimental}

Isolation of (-)-(5R,6Z)-dendrolasin-5-acetate (1) from Hypselodoris jacksoni: Eight individuals of $H$. jacksoni (21-40 $\mathrm{mm}$ in length) were collected from various dive sites in South East Queensland (specimens \#243, 244 Mudjimba Island, Mooloolaba S26 36'54", E153 06' 49"; \#75-77 and \#125-127 Shag Rock, North Stradbroke Island S27²4'49" E153³1'30”) between March and October of 2012. The whole animals were chopped, macerated in acetone $(20 \mathrm{~mL})$, sonicated for $2 \mathrm{~min}$ before being filtered through a cotton plug. The resulted filtrate was combined, concentrated under reduced pressure and partitioned between $\mathrm{Et}_{2} \mathrm{O}(3 \times 20 \mathrm{~mL})$ and water. The $\mathrm{Et}_{2} \mathrm{O}$ crude fraction $(39.2 \mathrm{mg}$ ) was resolved by NP flash column chromatography eluted with gradient solvent from $100 \%$ hexanes $\rightarrow 100 \%$ EtOAc to give ten fractions. The first and the second fraction (coded as HJF1-2) (21.3 mg) were combined based on their TLC profile, and yielded the major metabolites $(-)$-furodysinin $(3.8 \mathrm{mg}),(+)$-agassizin $(2.5 \mathrm{mg})$ and (-)-euryfuran $(0.8 \mathrm{mg})$ following NP HPLC separation using $100 \%$ hexanes. The fourth fraction coded as HJF4 (1.8 mg) was subjected to NP HPLC eluting with $2.5 \%$ EtOAc/hexanes to give (-)-dehydroherbadysidolide $(0.1 \mathrm{mg}),(+)$-pallescensone $(0.2 \mathrm{mg})$, and the new sesquiterpene $(-)-(5 R, 6 Z)$-dendrolasin-5-

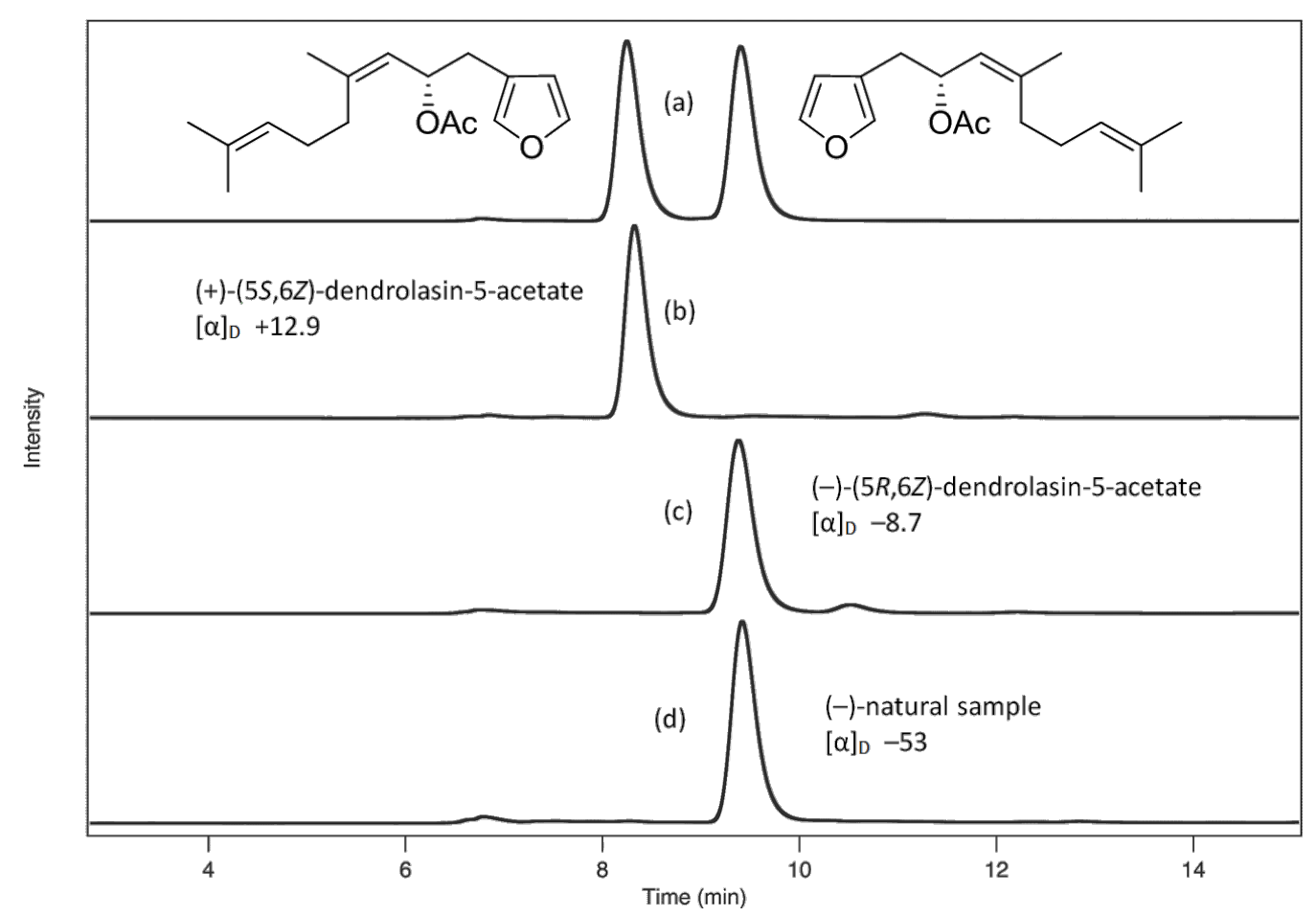

Figure 7: Enantioselective HPLC profiles (5\% isopropanol in $n$-hexane) of 1: (a) synthetic ( \pm ) mixture; (b) synthetic (+)-enantiomer; (c) synthetic (-)enantiomer; (d) natural sample from $H$. jacksoni. 
acetate $(1,0.1 \mathrm{mg}) .[\alpha]_{\mathrm{D}}^{24}-53\left(c 0.006, \mathrm{CHCl}_{3}\right) ;{ }^{1} \mathrm{H} \mathrm{NMR}$ $\left(\mathrm{CDCl}_{3}, 500 \mathrm{MHz}\right) \delta_{\mathrm{H}} 7.33$ (bs, 1H, H-1), 7.23 (bs, 1H, H-15), 6.27 (s, 1H, H-2), 5.64 (bdt, $J=6.4,9.3 \mathrm{~Hz}, 1 \mathrm{H}, \mathrm{H}-5$ ), 5.15 (d, $J=9.3 \mathrm{~Hz}, 1 \mathrm{H}, \mathrm{H}-6), 5.07$ (brt, $J=6.9 \mathrm{~Hz}, 1 \mathrm{H}, \mathrm{H}-10$ ), $2.73(\mathrm{dd}, J=6.7,14.5 \mathrm{~Hz}, 1 \mathrm{H}, \mathrm{H}-4 \mathrm{a}), 2.63$ (dd, $J=6.0,14.5$ $\mathrm{Hz}, 1 \mathrm{H}, \mathrm{H}-4 \mathrm{~b}$ ), 2.15-1.95 (overlapping, m, 4H, H-8, H-9), 1.72 (s, 3H, H-14), 1.67 (s, 3H, H-12), 1.59 (s, 3H, H-13); ${ }^{13} \mathrm{C}$ NMR $\left(\mathrm{CDCl}_{3}, 125 \mathrm{MHz}\right) \delta_{\mathrm{C}} 142.7$ (C-1), $141.5(\mathrm{C}-7)$, 140.1 (C-15), 132.0 (C-11), 123.9 (C-10), 123.7 (C-6), 120.2 (C-3), 111.8 (C-2), 70.7 (C-5), 32.5 (C-8), 30.7 (C-4), 26.5 (C-9), 25.7 (C-12), 23.3 (C-14), 17.6 (C-13); (+)-HRESIMS $m / z:[\mathrm{M}+\mathrm{Na}]^{+}$calcd. for $\mathrm{C}_{17} \mathrm{H}_{24} \mathrm{NaO}_{3}, 299.1618$; found, 299.1624 .

Procedure for Wittig rearrangement of 3-furylmethyl ether (6) [21]: To a solution of (E/Z)-3-furylmethyl ether $(\mathbf{6}, 200 \mathrm{mg})$ in THF $(10 \mathrm{~mL})$ was added dropwise first LDA $(3.64 \mathrm{~mL}$, $10 \mathrm{wt} \%$ suspension in hexane) followed by $t$-BuLi $(2.5 \mathrm{~mL}$, 1.6 $\mathrm{M}$ in hexanes;) at $-78{ }^{\circ} \mathrm{C}$ under Ar. After stirring for $1 \mathrm{~h}$ (the reaction mixture was allowed to warm to $0{ }^{\circ} \mathrm{C}$ ), the reaction mixture was quenched with sat. aq $\mathrm{NH}_{4} \mathrm{Cl}$ solution and the solvent was removed under vacuum. The residue was extracted with pentane $/ \mathrm{Et}_{2} \mathrm{O}(1: 1, \mathrm{v} / \mathrm{v})$. The extract was washed with brine and dried over $\mathrm{Na}_{2} \mathrm{SO}_{4}$. Evaporation of the solvent gave a residue, which was chromatographed on silica gel $(5.0 \mathrm{~g}$, hexanes/AcOEt 95:5) to afford the desired product ( $E / Z$ ratio $\sim 3: 1$ ) as a mixture of enantiomers ( $83 \mathrm{mg}, 39 \%$ yield). The $E$ and $Z$-isomers of 5-hydroxydendrolasin were then separated by NP HPLC (hexanes/EtOAc 90:10, flow rate $2 \mathrm{~mL} / \mathrm{min}$, refractive index detection, Waters $\mu$ Porasil ${ }^{\mathrm{TM}}$ column $10 \mu \mathrm{m}$, $300 \times 7.8 \mathrm{~mm})$ to give the individual $6 E\left((7 \mathbf{a}) ; 25.2 \mathrm{mg} ; t_{\mathrm{R}}=\right.$ $50.0 \mathrm{~min})$ and $6 Z\left((7 \mathrm{~b}) ; 8.4 \mathrm{mg} ; t_{\mathrm{R}}=40.0 \mathrm{~min}\right)$ isomers. Analytical enantioselective HPLC separation of the $Z$-isomer of 5-hydroxydendrolasin (7b) was performed on an Agilent 1200 series liquid chromatography system (isocratic conditions of $2 \%$ isopropanol in $n$-hexane, flow rate of $0.5 \mathrm{~mL} \mathrm{~min}^{-1}$ ) equipped with UV (214 nm) and ALP (Advanced Laser Polarimeter, PDR-Chiral Inc.) detectors and a Chiralpak AD column $(250 \times 4.6 \mathrm{~mm}$, Daicel Chemical Industries Ltd.). The preparative enantioselective HPLC purification of $7 \mathbf{b}$ used isocratic conditions ( $1.5 \%$ isopropanol in $n$-hexane, flow rate of $10 \mathrm{~mL}$ $\min ^{-1}$ ) with UV detection at $220 \mathrm{~nm}$ and a Chiralpak AD column $(250 \times 20 \mathrm{~mm}$, Daicel Chemical Industries Ltd. $)$ to give the $(+)$-enantiomer $(2.7 \mathrm{mg})$; $(-)$-enantiomer $(2.6 \mathrm{mg})$. The retention times were: $29.5 \mathrm{~min}((+)$-enantiomer $)$; $32.1 \mathrm{~min}((-)-$ enantiomer).

( \pm )-(E)-1-(furan-3-yl)-4,8-dimethylnona-3,7-dien-2-ol (7a) [21]: Colorless glass; ${ }^{1} \mathrm{H} \mathrm{NMR}\left(\mathrm{CDCl}_{3}, 500 \mathrm{MHz}\right) \delta_{\mathrm{H}} 7.37$ (s, $1 \mathrm{H}, \mathrm{H}-1), 7.29$ (s, 1H, H-15), 6.32 (s, 1H, H-2), 5.24 (d, $J=8.5$ $\mathrm{Hz}, 1 \mathrm{H}, \mathrm{H}-6$ ), 5.07 (brt, $J=7.1 \mathrm{~Hz}, 1 \mathrm{H}, \mathrm{H}-10$ ), 4.51 (q, $J=7.1$,
$13.6 \mathrm{~Hz}, 1 \mathrm{H}, \mathrm{H}-5), 2.66$ (dd, $J=7.1,14.4 \mathrm{~Hz}, 1 \mathrm{H}, \mathrm{H}-4 \mathrm{a}), 2.59$ (dd, $J=7.1,14.4 \mathrm{~Hz}, 1 \mathrm{H}, \mathrm{H}-4 \mathrm{~b}), 2.12-2.01$ (m, 4H, H-8 and $\mathrm{H}-9), 1.65$ (d, $\left.J=1.1 \mathrm{~Hz}, 3 \mathrm{H}, \mathrm{CH}_{3}-14\right), 1.69$ (s, 3H, $\mathrm{CH}_{3}-12$ ), $1.60\left(\mathrm{~s}, 3 \mathrm{H}, \mathrm{CH}_{3}-13\right) ;{ }^{13} \mathrm{C} \mathrm{NMR}\left(\mathrm{CDCl}_{3}, 125 \mathrm{MHz}\right) \delta_{\mathrm{C}} 142.9$ (C-1), 140.3 (C-15), 139.5 (C-7), 131.8 (C-11), 127.0 (C-3), 124.0 (C-10), 120.9 (C-6), 111.7 (C-2), 68.5 (C-5), 39.6 (C-8), 33.3 (C-4), 26.4 (C-9), 25.7 (C-12), 17.8 (C-13), 16.7 (C-14); $(+)$-LRESIMS $m / z: 257[\mathrm{M}+\mathrm{Na}]^{+}$.

( \pm )-(Z)-1-(furan-3-yl)-4,8-dimethylnona-3,7-dien-2-ol (7b): Colorless glass; ${ }^{1} \mathrm{H}$ NMR $\left(\mathrm{CDCl}_{3}, 500 \mathrm{MHz}\right) \delta_{\mathrm{H}} 7.37(\mathrm{~s}, 1 \mathrm{H}$, $\mathrm{H}-1), 7.29$ (s, 1H, H-15), 6.32 (s, 1H, H-2), 5.24 (d, $J=8.8 \mathrm{~Hz}$, $1 \mathrm{H}, \mathrm{H}-6$ ), 5.07 (brt, $J=5.4 \mathrm{~Hz}, 1 \mathrm{H}, \mathrm{H}-10$ ), 4.48 (q, $J=6.7,13.6$ $\mathrm{Hz}, 1 \mathrm{H}, \mathrm{H}-5$ ), 2.65 (dd, $J=7.2,14.4 \mathrm{~Hz}, 1 \mathrm{H}, \mathrm{H}-4 \mathrm{a}$ ), 2.58 (dd, $J$ $=7.2,14.4 \mathrm{~Hz}, 1 \mathrm{H}, \mathrm{H}-4 \mathrm{~b}), 2.12-2.01(\mathrm{~m}, 4 \mathrm{H}, \mathrm{H}-8$ and $\mathrm{H}-9)$, 1.74 (d, $\left.J=1.1 \mathrm{~Hz}, 3 \mathrm{H}, \mathrm{CH}_{3}-14\right), 1.69$ (s, 3H, $\left.\mathrm{CH}_{3}-12\right), 1.60$ (s, $\left.3 \mathrm{H}, \mathrm{CH}_{3}-13\right) ;{ }^{13} \mathrm{C} \mathrm{NMR}\left(\mathrm{CDCl}_{3}, 125 \mathrm{MHz}\right) \delta_{\mathrm{C}} 142.9(\mathrm{C}-1)$, 140.3 (C-15), 139.5 (C-7), 132.6 (C-11), 128.0 (C-3), 124.0 (C-10), 121.1 (C-6), 111.7 (C-2), 68.1 (C-5), 33.2 (C-8), 32.5 (C-4), 26.6 (C-9), 25.8 (C-12), 23.5 (C-14), 17.8 (C-13); (+)HRESIMS $m / z$ : $[\mathrm{M}+\mathrm{Na}]^{+}$calcd for $\mathrm{C}_{15} \mathrm{H}_{22} \mathrm{NaO}_{2}, 257.1512$; found, 257.1515 .

Procedure for acetylation of $( \pm)-(Z)-1-($ furan-3-yl)-4,8dimethylnona-3,7-dien-2-ol (7b): A portion of 7b (8.4 mg) was dissolved in dry pyridine $(0.5 \mathrm{~mL})$ and cooled in an ice bath. After the addition of acetic acid anhydride $(1.5 \mathrm{~mL})$ the mixture brought to $\mathrm{rt}$ and stirred for 1.5 hours. Toluene $(0.5 \mathrm{~mL})$ was added and the resulting azeotrope was evaporated under reduced pressure to give $( \pm)$ - $(6 Z)$-dendrolasin-5-acetate (1) $(6.4 \mathrm{mg}) ;{ }^{1} \mathrm{H}$ and ${ }^{13} \mathrm{C} \mathrm{NMR}$ data $\left(\mathrm{CDCl}_{3}, 500 \mathrm{MHz}\right)$ are identical to those of 1. (+)-LRESIMS $m / z 299[\mathrm{M}+\mathrm{Na}]^{+}$.

Procedure for acetylation of the $(+)$ isomer of $7 \mathbf{b}$ : A portion of the $(+)$ isomer of $7 \mathbf{b}(1.3 \mathrm{mg})$ was acetylated using the same procedure as for $\mathbf{7 b}$ to obtain (-)-(6Z)-dendrolasin-5-acetate (1, $0.9 \mathrm{mg})$; Colorless glass; $[\alpha]_{\mathrm{D}}-8.7\left(c 0.06, \mathrm{CHCl}_{3}\right) ;{ }^{1} \mathrm{H}$ and ${ }^{13} \mathrm{C}$ NMR data $\left(\mathrm{CDCl}_{3}, 500 \mathrm{MHz}\right)$ are the same as those of the 1. (+)-LRESIMS $m / z: 299[\mathrm{M}+\mathrm{Na}]^{+}$.

Procedure for acetylation of the (-)-isomer of $7 \mathbf{b}$ : A portion of the (-)-isomer of $7 \mathbf{b}(1.3 \mathrm{mg})$ was acetylated using the same procedure as for $\mathbf{7 b}$ to obtain (+)-(6Z)-dendrolasin-5-acetate (1, $1.1 \mathrm{mg})$; Colorless glass; $[\alpha]_{\mathrm{D}}+12.9\left(c 0.07, \mathrm{CHCl}_{3}\right) ;{ }^{1} \mathrm{H}$ and ${ }^{13} \mathrm{C} \mathrm{NMR}\left(\mathrm{CDCl}_{3}, 500 \mathrm{MHz}\right)$ are identical to those of $\mathbf{1} .(+)-$ LRESIMS $m / z: 299[\mathrm{M}+\mathrm{Na}]^{+}$.

Procedure for preparation of $(R)$ - and $(S)$-MPA esters of racemic (6Z)-5-hydroxydendrolasin (7b): ( \pm )-(6Z)-5Hydroxydendrolasin $(2.0 \mathrm{mg})$ was dissolved in dry DCM $(0.2 \mathrm{~mL})$ to which $(R)$-methoxyphenylacetic acid (MPA) 
$(0.83 \mathrm{mg}$ in $0.1 \mathrm{~mL}$ of DCM) was added, followed by DCC (2 equiv, $1.03 \mathrm{mg}$ in $0.1 \mathrm{~mL}$ of DCM) and DMAP (2 equiv, $0.61 \mathrm{mg}$ in $0.1 \mathrm{~mL}$ of DCM). The reaction was stirred at $\mathrm{rt}$ for $16 \mathrm{~h}$ and then filtered through a cotton wool plug. The solvent was removed by rotary evaporation and the residue passed through a pipette silica column eluted with hexanes/EtOAc (95:5) to give a racemic MPA ester $(0.8 \mathrm{mg})$. The racemic MPA ester was subsequently subjected to RP HPLC $\left(\mathrm{MeCN} / \mathrm{H}_{2} \mathrm{O}\right.$, 60:40; flow rate $1 \mathrm{~mL} / \mathrm{min}$, UV detection at $254 \mathrm{~nm}$, Phenomenex Gemini $5 \mu \mathrm{C} 18110 \AA$, $250 \times 4.60 \mathrm{~mm})$ to give the $R, R(0.2 \mathrm{mg})$ and $R, S$ diastereomers $(0.2 \mathrm{mg})$.

(R,R)-(6Z)-dendrolasin MPA ester (11a): Colorless glass; $[\alpha]_{\mathrm{D}}+10.1\left(c 0.01, \mathrm{CHCl}_{3}\right) ;{ }^{1} \mathrm{H} \mathrm{NMR}\left(\mathrm{CDCl}_{3}, 500 \mathrm{MHz}\right) \delta_{\mathrm{H}}$ 7.38-7.30 (m, 5H, MPA phenyl protons), 7.28 (brs, 1H, H-1), 7.14 (s, 1H, H-15), 6.20 (s, 1H, H-2), 5.66 (m, 1H, H-5), 5.04 (d, $J=9.8 \mathrm{~Hz}, 1 \mathrm{H}, \mathrm{H}-6), 5.02$ (brt, 1H, H-10), 4.70 (s, 1H, CH of MPA), 3.37 (s, 3H, OMe of MPA), 2.73 (dd, $J=7.2,14.7$ $\mathrm{Hz}, 1 \mathrm{H}, \mathrm{H}-4 \mathrm{a}), 2.63$ (dd, $J=7.2,14.7 \mathrm{~Hz}, 1 \mathrm{H}, \mathrm{H}-4 \mathrm{~b}), 2.16-2.10$ (m, 1H, H-8a), 1.98-1.86 (m, 1H, H-8b and 2H, m, H-9), 1.64 (s, 6H, $\mathrm{CH}_{3}-14$ and $\left.\mathrm{CH}_{3}-12\right), 1.56$ (s, 3H, $\mathrm{CH}_{3}-13$ ); (+)HRESIMS $m / z$ : $[\mathrm{M}+\mathrm{Na}]^{+}$calcd for $\mathrm{C}_{24} \mathrm{H}_{30} \mathrm{NaO}_{4}, 405.2036$; found, 405.2038 .

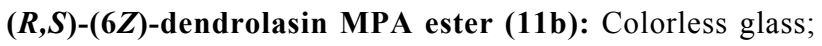
$[\alpha]_{\mathrm{D}}+10.7\left(c\right.$ 0.01, $\left.\mathrm{CHCl}_{3}\right) ;{ }^{1} \mathrm{H} \mathrm{NMR}\left(\mathrm{CDCl}_{3}, 500 \mathrm{MHz}\right) \delta_{\mathrm{H}}$ 7.38-7.36 (m, 5H, MPA phenyl protons), 7.17 (bs, 1H, H-1), 6.83 (s, 1H, H-15), 5.95 (s, 1H, H-2), 5.68 (m, 1H, H-5), 5.12 (d, $J=9.4 \mathrm{~Hz}, 1 \mathrm{H}, \mathrm{H}-6$ ), 5.04 (brt, $J=7.3 \mathrm{~Hz}, 1 \mathrm{H}, \mathrm{H}-10$ ), 4.68 (s, 1H, CH of MPA), 3.36 (s, 3H, OMe of MPA), 2.58 (dd, $J=$ 7.0, 14.7 Hz, 1H, H-4a), 2.51 (dd, $J=7.0,14.7 \mathrm{~Hz}, 1 \mathrm{H}, \mathrm{H}-4 \mathrm{~b}$ ), 2.24-2.20 (m, 1H, H-8a), 2.06-1.92 (m, 1H, H-8b and m, 2H, $\mathrm{H}-9), 1.71$ (d, $\left.J=1.0 \mathrm{~Hz}, 3 \mathrm{H}, \mathrm{CH}_{3}-14\right), 1.67$ (s, 3H, $\left.\mathrm{CH}_{3}-12\right)$, $1.58\left(\mathrm{~m}, 3 \mathrm{H}, \mathrm{CH}_{3}-13\right)$; (+)-HRESIMS $m / z$ : $[\mathrm{M}+\mathrm{Na}]^{+}$calcd for $\mathrm{C}_{24} \mathrm{H}_{30} \mathrm{NaO}_{4}, 405.2036$; found, 405.2043.

\section{Procedure for preparation of MPA ester of the $(+)$-isomer of} 7b: A portion of the $(+)$-isomer of $7 \mathbf{b}(1.3 \mathrm{mg})$ was treated with $(R)$-MPA $(0.83 \mathrm{mg}$ in $0.1 \mathrm{~mL}$ of DCM) using the same procedure as for the preparation of MPA ester of the racemic (6Z)-5hydroxydendrolasin (7b) to obtain the (+)-MPA ester (1.2 mg). The ${ }^{1} \mathrm{H}$ NMR data $\left(\mathrm{CDCl}_{3}, 500 \mathrm{MHz}\right)$ were identical to those for the $(R, R, 6 Z)$-dendrolasin MPA ester (11a). $[\alpha]_{\mathrm{D}}-93(c 0.08$, $\left.\mathrm{CHCl}_{3}\right) ;(+)$-LRESIMS $m / z: 405[\mathrm{M}+\mathrm{Na}]^{+}$.

\section{Procedure for preparation of MPA ester of the (-)-isomer of} 7b: A portion of the (-)-isomer of $\mathbf{7 b}(1.3 \mathrm{mg})$ was treated with $(R)$-MPA $(0.83 \mathrm{mg}$ in $0.1 \mathrm{~mL}$ of DCM$)$ using the same procedure as for the preparation of MPA ester of the racemic (6Z)-5hydroxydendrolasin (7) to obtain the (-)-MPA ester (1.0 mg). The ${ }^{1} \mathrm{H}$ NMR data $\left(\mathrm{CDCl}_{3}, 500 \mathrm{MHz}\right)$ are identical to those of the $(R, S, 6 Z)$-dendrolasin MPA ester (11b). $[\alpha]_{\mathrm{D}}-22(c 0.07$, $\left.\mathrm{CHCl}_{3}\right) ;(+)$-LRESIMS m/z: $405[\mathrm{M}+\mathrm{Na}]^{+}$.

Enantioselective HPLC experiments: Enantioselective HPLC analysis of the $( \pm)-(6 Z)$-dendrolasin-5-acetate (1) racemic mixture, the individual $5 R$ - and $5 S$-enantiomers of $(6 Z)$-dendrolasin-5-acetate, and the natural sample of $(-)-(5 R, 6 \mathrm{Z})$-dendrolasin-5-acetate, were performed using an Agilent 1200 series liquid chromatography system (isocratic conditions, 5\% isopropanol in $n$-hexane, flow rate of $0.5 \mathrm{~mL} \mathrm{~min}^{-1}$ ) equipped with UV (220 nm) and ALP (Advanced Laser Polarimeter, PDR-Chiral Inc.) detectors and a Chiralpak OJ column $(4.6 \times$ $250 \mathrm{~mm}$, Daicel Chemical Industries Ltd.). Retention times were: $(+)$-enantiomer, $>97 \%$ ee $8.3 \mathrm{~min}$; (-)-enantiomer, $>98.5 \%$ ee $9.4 \mathrm{~min}$; natural sample $9.4 \mathrm{~min}$.

\section{Supporting Information}

Supporting Information File 1 contains experimental details for the preparation of compound $\mathbf{6}$, spectroscopic data and other relevant information for compounds $1,7 \mathbf{b}, \mathbf{1 1 a}$, and $11 b$.

\section{Supporting Information File 1}

Experimental details and spectroscopic data. [http://www.beilstein-journals.org/bjoc/content/ supplementary/1860-5397-9-329-S1.pdf]

\section{Acknowledgements}

We thank the Australian Research Council and The University of Queensland for financial support, and Deb Aston for photography and her assistance with sample collections.

\section{References}

1. Blunt, J. W.; Copp, B. R.; Munro, M. H. G.; Northcote, P. T.; Prinsep, M. R. Nat. Prod. Rep. 2013, 20, 1-48. doi:10.1039/b207130b

2. Paul, V. J.; Ritson-Williams, R.; Sharp, K. Nat. Prod. Rep. 2011, 28, 345-387. doi:10.1039/c0np00040j

3. Pawlik, J. R. Antipredatory Defensive Roles of Natural Products from Marine Invertebrates. In Handbook of Marine Natural Products; Fattorusso, E.; Gerwick, W. H.; Taglialatela-Scafati, O., Eds.; Springer: London, 2012; pp 677-710. doi:10.1007/978-90-481-3834-0_12

4. Cimino, G.; Ghiselin, M. T. Chemoecology 1998, 8, 51-60. doi:10.1007/PL00001804

5. Cimino, G.; Ghiselin, M. T. Proc. Calif. Acad. Sci. 2009, 60, 175-422.

6. Gerwick, W. H.; Moore, B. S. Chem. Biol. 2012, 19, 85-98. doi:10.1016/j.chembiol.2011.12.014

7. Grode, S. H.; Cardellina, J. H., II. J. Nat. Prod. 1984, 47, 76-83. doi:10.1021/np50031a009

8. Avila, C.; Cimino, G.; Fontana, A.; Gavagnin, M.; Ortea, J.; Trivellone, E. J. Chem. Ecol. 1991, 17, 625-636. doi:10.1007/BF00982131 
9. Fontana, A.; Avila, C.; Martinez, E.; Ortea, J.; Trivellone, E.; Cimino, G. J. Chem. Ecol. 1993, 19, 339-356. doi:10.1007/BF00993700

10. Cimino, G.; Fontana, A.; Giménez, F.; Marin, A.; Mollo, E.; Trivellone, E.; Zubía, E. Experientia 1993, 49, 582-586. doi:10.1007/BF01955168

11. Fontana, A.; Giménez, F.; Marin, A.; Mollo, E.; Cimino, G. Experientia 1994, 50, 510-516. doi:10.1007/BF01920760

12. Fontana, A.; Trivellone, E.; Mollo, E.; Cimino, G.; Avila, C.; Martinez, E.; Ortea, J. J. Nat. Prod. 1994, 57, 510-513. doi:10.1021/np50106a011

13. da Cruz, J. F.; Gaspar, H.; Calado, G. Chemoecology 2012, 22, 47-53. doi:10.1007/s00049-011-0097-z

14. Fontana, A.; Ciavatta, M. L.; D'Souza, L.; Mollo, E.; Naik, C. G.; Parameswaran, P. S.; Wahidulla, S.; Cimino, G. J. Indian Inst. Sci. 2001, 81, 403-415.

15. McPhail, K.; Davies-Coleman, M. T.; Coetzee, P. J. Nat. Prod. 1998, 61, 961-964. doi:10.1021/np980051y

16. Pereira, F. R.; Berlinck, R. G. S.; Filho, E. R.; Veloso, K.; Ferreira, A. G.; Padula, V. Quim. Nova 2012, 35, 2194-2201. doi:10.1590/S0100-40422012001100018

17. Schulte, G.; Scheuer, P. J.; McConnell, O. J. Helv. Chim. Acta 1980, 63, 2159-2167. doi:10.1002/hlca.19800630805

18. Hochlowski, J. E.; Walker, R. P.; Ireland, C.; Faulkner, D. J. J. Org. Chem. 1982, 47, 88-91. doi:10.1021/jo00340a018

19. Schulte, G. R.; Scheuer, P. J. Tetrahedron 1982, 38, 1857-1863. doi:10.1016/0040-4020(82)80034-3

20. Karuso, P.; Scheuer, P. J. Molecules 2002, 7, 1-6. doi:10.3390/70100001-rev

21. Tsubuki, M.; Okita, H.; Kaneko, K.; Shigihara, A.; Honda, T. Heterocycles 2009, 77, 433-444. doi:10.3987/COM-08-S(F)40

22. Kakou, Y.; Crews, P.; Bakus, G. J. J. Nat. Prod. 1987, 50, 482-484. doi:10.1021/np50051a023

23. Tran, N. H.; Hooper, J. N. A.; Capon, R. J. Aust. J. Chem. 1995, 48, 1757-1760. doi:10.1071/CH9951757

24. Chakraborty, A.; Kar, G. K.; Ray, J. K. Tetrahedron 1997, 53 , 8513-8518. doi:10.1016/S0040-4020(97)00509-7

25. Freire, F.; Calderón, F.; Seco, J. M.; Fernandez-Mayoralas, A.; Quinõá, E.; Riguera, R. J. Org. Chem. 2007, 72, 2297-2301. doi:10.1021/jo061939r

\section{License and Terms}

This is an Open Access article under the terms of the Creative Commons Attribution License (http://creativecommons.org/licenses/by/2.0), which permits unrestricted use, distribution, and reproduction in any medium, provided the original work is properly cited.

The license is subject to the Beilstein Journal of Organic Chemistry terms and conditions:

(http://www.beilstein-journals.org/bjoc)

The definitive version of this article is the electronic one which can be found at: doi:10.3762/bjoc.9.329 